\title{
Sowing strategies for slow-establishing pasture species on a North Otago dairy farm
}

\author{
R.G.M. HURST ${ }^{1}$, A.D. BLACK ${ }^{2}$, R.J. LUCAS ${ }^{2}$ and D.J. MOOT ${ }^{2}$ \\ ${ }^{1} R D$ 4K, Oamaru, North Otago \\ ${ }^{2}$ Soil, Plant and Ecological Sciences Division, P.O. Box 84, Lincoln University, Canterbury \\ ²Blacka1@lincoln.ac.nz
}

\begin{abstract}
Slow-establishing, high quality, pasture species are frequently added to standard ryegrass-white clover seed mixtures in an effort to improve pasture nutritive value. However, intense competition during establishment can suppress these species. Four alternative sowing strategies (Treatment 1: temporal separation of species (clovers sown in November 1998 before ryegrass direct-drilled at $10 \mathrm{~kg} / \mathrm{ha}$ in March 1999); Treatment 2: substitution of ryegrass with slower-establishing timothy; Treatments 3 and 4: physical separation (alternate drill rows) of slower-establishing species from lower than average ryegrass seeding rates $(3.5 \mathrm{~kg} /$ ha or $8 \mathrm{~kg} / \mathrm{ha}$ )) were used on a commercial North Otago dairy farm. Total dry matter (DM) production after 16 months was greater from pastures initially sown with ryegrass (19.1 t DM/ ha) (Treatments 3 and 4) than when ryegrass sowing was delayed or substituted with timothy (15.2 t DM/ha) (Treatments 1 and 2). The percentage of red plus white clover was similar in all pastures at 16 months of age and averaged $54 \%$, compared with less than $1 \%$ for caucasian clover. Timothy sown without ryegrass contributed $42 \%$ of production (Treatment 2), compared with $7 \%$ when sown with ryegrass (Treatments 3 and 4). Ryegrass composition was similar (43\%) regardless of sowing rate (Treatments 3 and 4) and sowing date (Treatment 1). This on-farm study demonstrated successful establishment of red and white clover in all four treatments but timothy and caucasian clover were suppressed by the inclusion of low rates of ryegrass.
\end{abstract}

Keywords: botanical composition, competition, dry matter production, Lolium perenne, Phleum pratense, seeding rates, Trifolium ambiguum, $T$. pratense, $T$. repens

\section{Introduction}

Maximising animal production through increased intake of high quality pasture species is a recurring theme of sheep (Everest \& Scales 1983; Brown 1990; Stevens et al. 1993) and dairy (Harris et al. 1997) research. Traditionally, high quality pasture has been characterised as that containing a high white clover (Trifolium repens) content (Rattray et al. 1987). However, Brown (1990) indicated this was seldom achieved in practice. Species such as chicory (Cichorium intybus), red clover (T. pratense) and timothy (Phleum pratense) may be added to a standard ryegrass (Lolium perenne) and white clover pasture mix in an attempt to increase the proportion of high quality forage. However, the intense competition created during establishment can compromise the success of slower-establishing species (Moot et al. 2000) particularly if ryegrass seeding rates greater than $10 \mathrm{~kg} / \mathrm{ha}$ are included (Cullen 1958; Dumbleton 1997). This is particularly important when sowing caucasian clover (T. ambiguum), which is extremely sensitive to competition during establishment (Hill \& Mulcahy 1995), but can increase the total legume content of pastures after the initial legume dominant phase (Black \& Lucas 2000; Black et al. 2000).

The objective of this research was to develop onfarm sowing strategies to improve the establishment of slow emerging, high nutritive value pasture species. Specifically, temporal and physical separation of slow establishing species from lower than average ryegrass seeding rates, and the substitution of ryegrass with slower establishing timothy were the strategies used. Results presented include dry matter (DM) production and botanical composition of pastures from a spring sowing on an irrigated commercial dairy farm through a 16-month establishment phase (Thom et al. 1987).

\section{Materials and methods}

The experiment was established on a silt loam soil, on a commercial dairy farm $35 \mathrm{~km}$ northwest of Oamaru, North Otago. Prior to sowing, the 3-ha paddock was re-developed for border-dyke flood irrigation and lightly cultivated. Sulphur superphosphate (8\% P, 20\% S) was applied at $250 \mathrm{~kg} / \mathrm{ha}$ in August 1998 and lime at $2.5 \mathrm{t} /$ ha in October 1998. The paddock was sown on 5 November 1998 with three replicates of four treatments in a randomised complete block design. Plots were as long $(150 \mathrm{~m})$ and half as wide $(13 \mathrm{~m})$ as each irrigation border strip. A roller drill, capable of sowing two seed mixtures in alternate rows, was used to physically 
separate seed of different species in Treatments 3 and 4. Treatment details and corresponding seed mixtures were as follows:

Treatment 1: Temporal separation of species.

'Pawera' red clover ( $1 \mathrm{~kg} / \mathrm{ha})$, 'Sustain' white clover ( $1 \mathrm{~kg} / \mathrm{ha})$ and 'Endura' caucasian clover ( $2 \mathrm{~kg} / \mathrm{ha})$ were sown in 150-mm rows on 5 November 1998. 'Dobson' perennial ryegrass $(10 \mathrm{~kg} / \mathrm{ha})$ was direct-drilled 140 days later on 26 March 1999 in 150-mm rows, parallel to the original rows.

Treatment 2: Substitution of ryegrass with slowerestablishing timothy.

The same clover mixture as in Treatment 1 was used with the addition of 'Charlton' timothy $(2 \mathrm{~kg} / \mathrm{ha})$, as an alternative to faster-establishing ryegrass, sown in 150-mm rows on 5 November 1998.

Treatments 3 and 4: Physical separation of slowerestablishing species from lower than average ryegrass seeding rates.

Caucasian clover ( $2 \mathrm{~kg} / \mathrm{ha})$, white clover $(1 \mathrm{~kg} / \mathrm{ha})$ and timothy $(2 \mathrm{~kg} / \mathrm{ha})$ sown together in alternate $75-\mathrm{mm}$ rows with 'Dobson' ryegrass at $3.5 \mathrm{~kg} / \mathrm{ha}$ or $8 \mathrm{~kg} / \mathrm{ha}$ plus red clover $(1 \mathrm{~kg} / \mathrm{ha})$ in every second row on 5 November 1998.

Caucasian clover was inoculated with the specific Rhizobium strain ICC148 (Pryor et al. 1998). After sowing, normal farm fertility management was applied with Cropmaster $15(15 \% \mathrm{~N}, 10 \% \mathrm{P}, 10 \% \mathrm{~K}, 8 \% \mathrm{~S})$ at $250 \mathrm{~kg} / \mathrm{ha}$ in December 1998, 15\% potash superphosphate $(8 \% \mathrm{P}, 8 \% \mathrm{~K}, 10 \% \mathrm{~S})$ at $250 \mathrm{~kg} / \mathrm{ha}$ and urea $(46 \% \mathrm{~N})$ at $80 \mathrm{~kg} / \mathrm{ha}$ in March 1999 , sulphur superphosphate at $250 \mathrm{~kg} / \mathrm{ha}$ in July 1999 , and $30 \%$ potash superphosphate $(6 \% \mathrm{P}, 15 \% \mathrm{~K}, 8 \% \mathrm{~S})$ at $250 \mathrm{~kg} /$ ha in March 2000. Plots were sprayed for thistles with MCPB at 4 1/ha in December 1998 and were irrigated regularly over summer as part of the normal farm rotation. The experiment was lightly grazed with cows or heifers at monthly intervals from December 1998 to April 1999. Monthly grazing was initiated again in August 1999.

\section{Measurements}

Seedlings were counted 43 days after sowing (DAS) within four random $0.2 \mathrm{~m}^{2}$ quadrats per plot and the percentage of seed sown that had produced seedlings was calculated. At this time, four spade spits $(500 \mathrm{x}$ $150 \mathrm{~mm}$ ) were dug to randomly sample 10 plants along drill rows in each treatment. Samples were washed and dry weights of shoots (above-ground herbage) and roots determined. A second measurement of seedling dry weight was repeated at 83 DAS.

Dry matter production was measured before each grazing on seven occasions between January 1999 and March 2000 (excluding the April-September 1999 period) with a rising plate meter at 100 random points per plot. The rising plate meter was calibrated against five DM cuts per treatment and recalibrated in autumn, spring and mid summer according to L'Huillier \& Thomson (1988). Botanical composition was determined in March 1999, October 1999 and February 2000 by cutting 20 random samples across each plot for herbage dissection. Grass components of total herbage samples from the October harvest were analysed for nitrogen content (N\%).

\section{Statistical analysis}

Significant $(\mathrm{P}<0.05)$ treatment differences were determined using one-way analysis of variance and standard errors of means are presented. Data were not transformed for analysis.

\section{Results}

\section{Dry matter production}

The total DM produced after 16 months from sowing to March 2000 was greater $(\mathrm{P}<0.05)$ from pastures initially sown with ryegrass (Treatments 3 and 4 ) at $19.1 \mathrm{t} \mathrm{DM} / \mathrm{ha}$, than when ryegrass sowing was delayed or substituted with timothy (Treatments 1 and 2) at $15.2 \mathrm{t} \mathrm{DM} / \mathrm{ha}$ (Table 1). The difference in DM production between Treatments 3 and 4 vs. Treatments 1 and 2 was significant $(\mathrm{P}<0.05)$ at each measurement date except autumn 1999. In March 2000, DM production also differed $(\mathrm{P}<0.05)$ between pasture

Table 1 Dry matter production ( $\mathrm{DM} / \mathrm{ha}$ ) from establishing dairy pastures over 16 months from sowing in November 1998. Treatments 1 : spring sown clover, $10 \mathrm{~kg} /$ ha perennial ryegrass direct-drilled in autumn; 2 : timothy plus clovers; 3 and 4: clovers with timothy and $3.5 \mathrm{~kg} / \mathrm{ha}$ or $8 \mathrm{~kg} / \mathrm{ha}$ ryegrass.

\begin{tabular}{|c|c|c|c|c|c|c|c|c|}
\hline Treatment & $\begin{array}{c}\text { Jan } \\
1999\end{array}$ & $\begin{array}{c}\text { Mar } \\
1999\end{array}$ & $\begin{array}{c}\text { Oct } \\
1999\end{array}$ & $\begin{array}{c}\text { Dec } \\
1999\end{array}$ & $\begin{array}{c}\text { Jan } \\
2000\end{array}$ & $\begin{array}{c}\text { Feb } \\
2000\end{array}$ & $\begin{array}{c}\text { Mar } \\
2000\end{array}$ & $\begin{array}{c}\text { Total DM } \\
\text { (t /ha) }\end{array}$ \\
\hline 1 & 1.0 & 2.7 & 2.2 & 2.4 & 2.3 & 2.1 & 2.1 & 14.8 \\
\hline 3 & 2.2 & 3.2 & 2.7 & 2.8 & 2.7 & 3.1 & 2.7 & 19.4 \\
\hline 4 & 2.4 & 2.5 & 2.6 & 2.9 & 2.8 & 3.0 & 2.6 & 18.8 \\
\hline SEM & 0.16 & 0.32 & 0.10 & 0.11 & 0.09 & 0.08 & 0.08 & 0.56 \\
\hline
\end{tabular}


direct-drilled with ryegrass (2.1 t DM/ ha) (Treatment 1) and pasture with timothy as the sole grass species $(1.8 \mathrm{t}$ DM/ha) (Treatment 2).

\section{Botanical composition}

In March, the four 5-month-old pastures differed $(\mathrm{P}<0.05)$ in their percentage of legume and timothy (Figure 1). Red clover averaged $35 \%$ in Treatments 1 and 2, compared with $11 \%$ in Treatments 3 and $4(\mathrm{P}<0.05)$. White clover at 50\% was the dominant legume in Treatment 1 , but only contributed $5 \%$ of production in Treatments 3 and $4(\mathrm{P}<0.05)$. Caucasian clover averaged $11 \%$ and timothy $40 \%$ when sown without ryegrass in Treatments 1 and 2, but both contributed less than $2 \%$ of production $(\mathrm{P}<0.05)$ in Treatments 3 and 4 where ryegrass was dominant at $81 \%$.

In the 11-month-old pastures (October 1999), white clover at $60 \%$ was the dominant legume when initially sown without ryegrass (Treatments 1 and 2), compared with $16 \%(\mathrm{P}<0.05)$ when ryegrass was included in the pasture mix (Treatments 3 and 4). In contrast, caucasian clover averaged less than $1 \%$ in all four treatments. Red clover averaged 6\% in Treatments 1 and 2, compared with $15 \%$ in Treatments 3 and 4 $(\mathrm{P}<0.05)$. Timothy contributed $43 \%$ of production in Treatment 2, but remained less than $2 \%$ in Treatments 3 and $4(\mathrm{P}<0.05)$. Ryegrass composition was similar at $67 \%$ in the $3.5 \mathrm{~kg} / \mathrm{ha}$ and $8 \mathrm{~kg} / \mathrm{ha}$ ryegrass sowing rate treatments (Treatments 3 and 4), but was only $30 \%(\mathrm{P}<0.05)$ when direct-drilled into the established clover sward (Treatment 1 ).

By the end of summer in February 2000, the proportions of caucasian clover (less than $1 \%$ ), white clover $(37 \%)$ and red clover (17\%) were significantly different $(\mathrm{P}<0.05)$, but the legume content was similar in all treatments. Timothy contributed $42 \%$ of production in Treatment 2, compared with $7 \%$ in Treatments 3 and $4(\mathrm{P}<0.05)$. Ryegrass composition averaged $33 \%$ regardless of sowing rate (Treatments 3 and 4 ) and sowing date (Treatment 1 ).

\section{Nitrogen \% of timothy and ryegrass in October 1999}

Nitrogen\% in grass herbage was greatest $(\mathrm{P}<0.05)$ for timothy (3.8\%) in Treatment 2, 11 months after sowing. Nitrogen $\%$ in ryegrass herbage averaged $3.2 \%$ in Treatments 1 and 3, compared with $2.8 \%(\mathrm{P}<0.05)$ when ryegrass was initially sown at $8 \mathrm{~kg} / \mathrm{ha}$ in Treatment 4.
Botanical composition (\%) of establishing dairy pastures in March 1999, October 1999 and February 2000 after sowing in November 1998 (RG: perennial ryegrass, TM: timothy, CC: caucasian clover, WC: white clover, RC: red clover). Treatments 1: spring sown clover, $10 \mathrm{~kg} /$ ha ryegrass direct drilled in autumn; 2: timothy plus clovers; 3 and 4: clovers with timothy and $3.5 \mathrm{~kg} / \mathrm{ha}$ or $8 \mathrm{~kg} / \mathrm{ha}$ ryegrass.

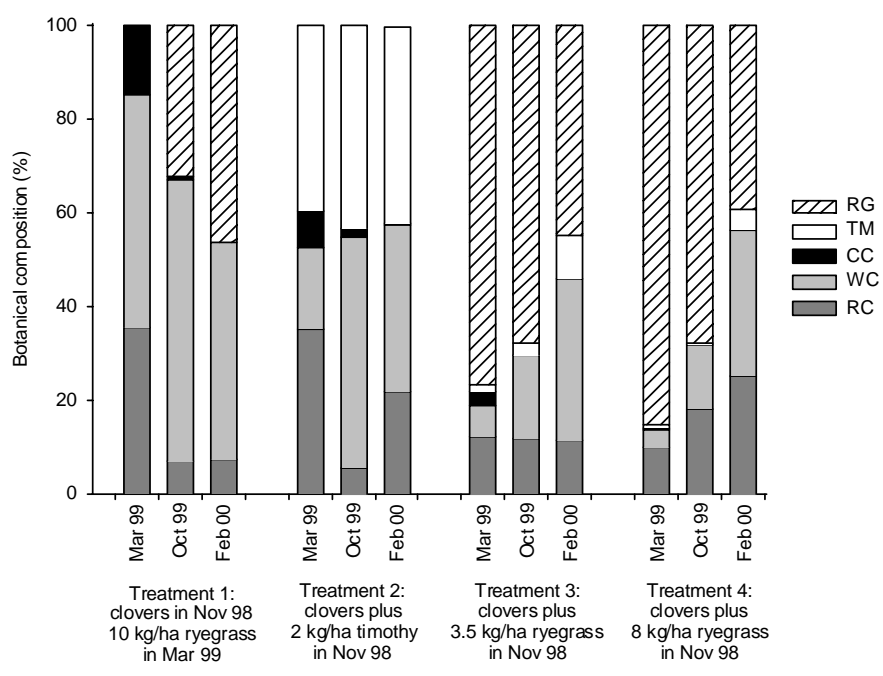

\section{Seedling dry weight}

Seedlings of caucasian and white clovers and timothy were smaller $(\mathrm{P}<0.05)$ than red clover and ryegrass at 43 DAS (Figure 2). After another 40 days (83 DAS), caucasian clover and timothy seedlings remained relatively small $(\mathrm{P}<0.05)$ while white clover had increased its size ranking so that individual white clover plant dry weights were similar to ryegrass. Red clover plants were smaller $(\mathrm{P}<0.05)$ than ryegrass at $43 \mathrm{DAS}$, but at $83 \mathrm{DAS}$, were similar to ryegrass in Treatments 3 and 4 and were largest when established without ryegrass in Treatments 1 and 2 . Ryegrass competition in Treatments 3 and 4 reduced the size of all clover seedlings compared with those grown with timothy in Treatment 2 .

Root:shoot ratios of caucasian $(0.36: 1)$, white $(0.23: 1)$ and red $(0.18: 1)$ clover differed $(\mathrm{P}<0.05)$ but were similar across all four treatments at 43 DAS (Figure 2). However at 83 DAS, caucasian clover had the highest $(\mathrm{P}<0.05)$ root:shoot ratio $(0.69: 1)$ compared with white $(0.19: 1)$ and red $(0.17: 1)$ clovers.

\section{Seedling populations in December 1998}

Seedling numbers per $\mathrm{m}^{2}$ showed that establishment across all treatments was most successful for red (25/ $\mathrm{m}^{2}$ ) and white $\left(49 / \mathrm{m}^{2}\right)$ clovers equating to $74 \%$ of the sown seed at 43 DAS in December 1998 (Table 2). For caucasian clover, $57 \%$ of the sown seed established $\left(29 / \mathrm{m}^{2}\right)$ when sown without ryegrass (Treatments 1 
and 2), compared with only $40 \%\left(20 / \mathrm{m}^{2}\right)$ $(\mathrm{P}<0.05)$ in the presence of ryegrass (Treatments 3 and 4 ). Similarly, $66 \%$ of the timothy seed sown established $\left(219 / \mathrm{m}^{2}\right)$ when sown without ryegrass (Treatment 2 ), compared with $54 \%$ $\left(180 / \mathrm{m}^{2}\right)$ when ryegrass was included in the pasture mix (Treatments 3 and 4$)(\mathrm{P}<0.05)$. Ryegrass averaged about 120 seedlings per $\mathrm{m}^{2}$ in Treatments 3 and 4, which suggested the percentage establishment was halved $(\mathrm{P}<0.05)$ at the higher ryegrass sowing rate.

\section{Discussion}

The total pasture yields measured after 16 months of production (Table 1) and the botanical composition 15 months after sowing (Figure 1) show that highly productive pastures were established using all four sowing strategies. However, the yield, botanical composition and nutritive value of pastures were all influenced by the establishment method.

The difference in total production of about $4 \mathrm{t} \mathrm{DM} / \mathrm{ha}$ was probably owing to the rapid ryegrass establishment (Treatments 3 and 4) and the greater grazing preference of cattle for the clover (Treatment 1) and timothy-plus-clover (Treatment 2) pastures compared with the ryegrass-dominant pastures. Post-grazing pasture mass was not measured but preference for Treatments 1 and 2 was observed. The consequence would be greater utilisation of clover and timothy leading to a reduced post-

Table 2 Seedling number per $\mathrm{m}^{2}$ and percentage of the sown seed established of each species 43 days after sowing. Treatments 1: spring sown clover, $10 \mathrm{~kg} / \mathrm{ha}$ perennial ryegrass direct-drilled in autumn; 2: timothy plus clovers; 3 and 4: clovers with timothy and $3.5 \mathrm{~kg} / \mathrm{ha}$ or $8 \mathrm{~kg} / \mathrm{ha}$ ryegrass.

\begin{tabular}{|c|c|c|c|c|c|}
\hline & \multicolumn{5}{|c|}{ - Treatment } \\
\hline & 1 & 2 & 3 & 4 & SEM \\
\hline & \multicolumn{5}{|c|}{ Seedlings per $m^{2}$} \\
\hline Caucasian clover & 29 & 28 & 19 & 21 & 4.2 \\
\hline White clover & 54 & 49 & 49 & 47 & 2.7 \\
\hline Red clover & 29 & 25 & 17 & 27 & 5.1 \\
\hline Timothy & - & 219 & 184 & 175 & 15.7 \\
\hline \multirow[t]{2}{*}{ Perennial ryegrass } & - & - & 115 & 131 & 7.8 \\
\hline & \multicolumn{5}{|c|}{$\%$ of the sown seed established } \\
\hline Caucasian clover & 58 & 56 & 38 & 41 & 8.4 \\
\hline White clover & 80 & 73 & 72 & 70 & 4.1 \\
\hline Red clover & 88 & 74 & 53 & 82 & 15.3 \\
\hline Timothy & - & 66 & 55 & 53 & 4.7 \\
\hline Perennial ryegrass & - & - & 82 & 41 & 1.3 \\
\hline
\end{tabular}

Figure 2 Seedling shoot and root dry weight per plant of each species at 43 and 83 days after sowing in November 1998. Treatments 1: spring sown clover, $10 \mathrm{~kg} / \mathrm{ha}$ perennial ryegrass direct drilled in autumn; 2: timothy plus clovers; 3 and 4: clovers with timothy and $3.5 \mathrm{~kg} / \mathrm{ha}$ or $8 \mathrm{~kg} / \mathrm{ha}$ ryegrass. Vertical bars represent one standard error of the mean.
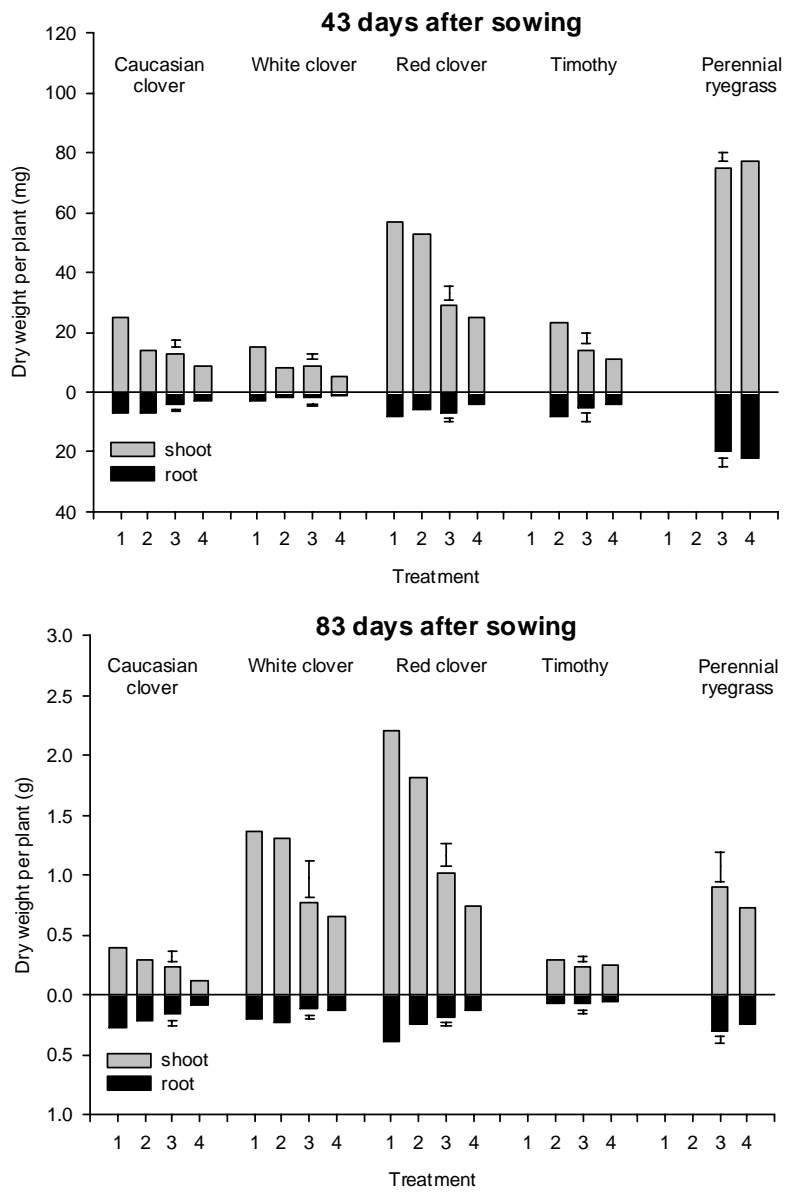

grazing mass and a longer lag phase at the start of regrowth after grazing. However, the difference in total production may have been greater if pasture production from the two grazings during the cool April-September period had been measured and included because ryegrass may have been more winter active than the clovers.

In February 2000, all four 16-month-old pastures were about 50/50 legume and grass but they reached this point in contrasting ways. Treatment 1 was initially pure clover and the direct-drilled ryegrass never suffered nitrogen deficiency $(3.2 \% \mathrm{~N}$ in October 1999). The timothy-plus-clover treatment had 50-60\% legume throughout the first 16 months and the timothy was also never obviously nitrogen deficient $(3.8 \% \mathrm{~N})$. In 
contrast, clover productivity was suppressed in pastures initially sown with ryegrass (Treatments 3 and 4). Total legume content in 5-month-old pastures was $21 \%$ when sown with ryegrass at $3.5 \mathrm{~kg} / \mathrm{ha}$, and only $12 \%$ with ryegrass at $8 \mathrm{~kg} / \mathrm{ha}$. This lower legume content in Treatments 3 and 4 than Treatments 1 and 2 indicates the negative effect of ryegrass seedling competition on clover establishment. In particular, lack of clover in Treatment 4 resulted in nitrogen deficiency in the ryegrass, indicated by strongly contrasting dark green urine patches and a decline in nitrogen-deficient grass vigour as legume content increased through spring 1999 to February 2000 (Figure 1 and Table 3).

The suppression of red and white clovers and timothy at the very low ryegrass seeding rate of $3.5 \mathrm{~kg} /$ ha is a measure of the poor sociability of ryegrass with slower-establishing species. The $8 \mathrm{~kg} /$ ha ryegrass seeding rate used in Treatment 4 gives an indication of how legume content would decline even more when recommended ryegrass seeding rates of 16 to $20 \mathrm{~kg} /$ ha are used. Cullen (1958) demonstrated emphatically the effects of high ryegrass sowing rates on slow establishing pasture species and concluded that low (4-10 kg/ha) rates of ryegrass were needed if seedlings of slower establishing, small-seeded species such as cocksfoot (Dactylis glomerata), timothy, and white clover were to be encouraged.

The combination of species-specific thermal time (Tt) requirements for seedling emergence and seedling growth can provide an explanation for the poor sociability of ryegrass observed with slow-establishing species (Moot et al. 2000). For example, white clover and ryegrass have similar $\mathrm{Tt}$ requirements for emergence (about 150 growing degree-days $\left({ }^{\circ} \mathrm{Cd}\right)$ ) and would therefore have emerged at about the same time. The slow seedling growth of white clover after 43 days is consistent with previous reports (Moot et al. 2000) and can be related to its small seed size (Brougham 1954). By March 1999, white clover was the dominant legume in all treatments, which was probably owing to stolon proliferation once the seedlings had established (Toddhunter 1997). However, white clover is sensitive to competition from ryegrass seeding rates beyond the demonstrated 8 kg/ha (Cullen 1956; Dumbleton 1997).

Red clover, with a heavier seed and a lower $\mathrm{Tt}$ requirement for emergence than white clover (about $120{ }^{\circ} \mathrm{Cd}$ ) (Moot et al. 2000), demonstrated seedling growth comparable with ryegrass at 43 DAS. A high Tt requirement for emergence (about $230{ }^{\circ} \mathrm{Cd}$ ) (Moot et al. 2000) and a low seed weight also provide explanations for the traditional classification of timothy as a slow-establishing pasture species (Sangakkara \& Roberts 1981; Stevens et al. 1993; Andrews et al.
1997). In this experiment, timothy was successful as the sole grass species but was sensitive to competition from the lowest seeding rate of ryegrass. Poor competitive ability, coupled with selective overgrazing, often prevents timothy from making a significant contribution to the performance of pastures containing other perennial grass species (Charlton \& Stewart 2000). However, pastures with timothy as the sole grass species have demonstrated superior goat liveweight gains (Stevens et al. 1992) and dairy cow performance (Johnson \& Thomson 1996) over perennial ryegrass pastures, through increased legume contents and grass forage nutritive value.

The loss of caucasian clover from sowings with ryegrass, timothy or red and white clover in this study adds to its reputation as an extremely slow-establishing species. Caucasian clover partitions a greater proportion of dry matter production to roots rather than shoots during its first year (Genrich et al. 1998; Widdup et al. 1998). Therefore, it is disadvantaged when competition for light is intense (Hill \& Mulcahy 1995). Establishing caucasian clover as the sole species in spring and directdrilling with ryegrass in the following autumn appears to be the only option for successful caucasian clover establishment on fertile lowland sites. This strategy has been successful in previous experimental sowings (Black et al. 2000; Watson et al. 1996). Although there is an initial cost in reduced first year production, successful establishment of caucasian clover will enhance the legume content in permanent pastures (Black et al. 2000; Moss et al. 1996). Caucasian clover can complement white clover for many years beyond the normal 3-year effective contribution of red clover. This outcome provides a valid reason for accepting the slow establishment and poor initial production of caucasian clover in the expectation of greater long-term production from pastures which will have much greater total legume content.

\section{Conclusions}

This on-farm study showed the value of alternative strategies for sowing high quality, slow establishing pasture species. Specific conclusions were:

1. Establishing clovers in spring and direct-drilling ryegrass in the following autumn will produce pastures with high legume content.

2. Timothy is a good companion grass for clovers and will produce high quality pasture if sown without ryegrass. If necessary ryegrass can be easily directdrilled later.

3. Caucasian clover is sensitive to all competing species and should be sown alone in spring with grass direct- 
drilled later. Post-emergence herbicides may be required to reduce weed competition.

4. Red and white clovers were less affected by low sowing rates of ryegrass compared with timothy and caucasian clover which were most sensitive to ryegrass competition.

5. On irrigated fertile soils, ryegrass sowing rates in spring of less than $8 \mathrm{~kg} / \mathrm{ha}$ are recommended to ensure satisfactory establishment of red and white clovers.

\section{ACKNOWLEDGEMENTS}

David Geary and Dr Keith Pollock for their assistance in field measurements, and the C. Alma Baker and Struthers Trusts for providing A.D. Black with financial assistance from post-graduate scholarships.

\section{REFERENCES}

Andrews, M.; Douglas, A.; Jones, A.V.; Milburn, C.E.; Porter, D.; McKenzie, B.A. 1997. Emergence of temperate pasture grasses from different sowing depths: importance of seed weight, coleoptile plus mesocotyl length and shoot strength. Annals of Applied Biology 130: 549-560.

Black, A.D.; Lucas, R.J. Caucasian clover was more productive than white clover in grass mixtures under drought conditions. Proceedings of the New Zealand Grassland Association 62: 183-188.

Black, A.D.; Pollock, K.M.; Lucas, R.J.; Amyes, J.M.; Pownall, D.B.; Sedcole, J.R. 2000. Caucasian clover/ ryegrass produced more legume than white clover/ ryegrass pastures in a grazed comparison. Proceedings of the New Zealand Grassland Association 62: 69-74.

Brougham, R.W. 1954. Pasture establishment studies I \& II. New Zealand Journal of Science and Technology A35: 518-549.

Brown, C. 1990. An integrated herbage production system for Southland and South Otago. Proceedings of the New Zealand Grassland Association 52: 119122.

Charlton, J.F.L.; Stewart, A.V. 2000. Timothy - the plant and its use on New Zealand farms. Proceedings of the New Zealand Grassland Association 62: 147153.

Cullen, N.A. 1958. Pasture establishment studies at Invermay Research Station. Proceedings of the New Zealand Grassland Association 20: 138-147.

Dumbleton, A.J. 1997. White clover and chicory production from four sowing dates with five rates of ryegrass. B.Agr.Sc. Honours Dissertation. Lincoln University.
Everest, P.G.; Scales, G.H. 1983. Pre and post weaning growth rates of ewes and lambs in the South Island. pp. 41-49. In: Lamb growth. Ed. Familton, A.S. Lincoln College, Canterbury.

Genrich, K.C.; Sheaffer, C.C.; Ehlke, N.J. 1998. Crop ecology, production and management: Kura clover growth and development during the seeding year. Crop Science 38: 735-741.

Harris, S.L.; Clark, D.A.; Auldist, M.J.; Waugh, C.D.; Laboyrie, P.G. 1997. Optimum white clover content for dairy pastures. Proceedings of the New Zealand Grassland Association 59: 29-33.

Hill, M.J.; Mulcahy, C. 1995. Seedling vigour and rhizome development in Trifolium ambiguum $\mathrm{M}$. Bieb. (Caucasian clover) as affected by density of companion grasses, fertility, drought and defoliation in the first year. Australian Journal of Agricultural Research 46: 807-819.

Johnson, R.J.; Thomson, N.A. 1996. Effect of pasture species on milk yield and milk composition. Proceedings of the New Zealand Grassland Association 57: 151-156.

L'Huillier, P.J.; Thomson, N.A. 1988. Estimation of herbage mass in ryegrass-white clover dairy pastures. Proceedings of the New Zealand Grassland Association 49: 117-122.

Moot, D.J.; Scott, W.R.; Roy, A.M.; Nicholls, A.C. 2000. Base temperature and thermal time requirements for germination and emergence of temperate pasture species. New Zealand Journal of Agricultural Research 43: 15-25.

Moss, R.A.; Burton, R.N.; Allan, B.E. 1996. Productivity of caucasian clover based pastures under irrigation. Proceedings of the New Zealand Grassland Association 58: 177-181.

Pryor, H.N.; Lowther, W.L.; McIntyre, H.J.; Ronson, C.W. 1998. An inoculant Rhizobium strain for improved establishment and growth of hexaploid Caucasian clover (Trifolium ambiguum). New Zealand Journal of Agricultural Research 41: 179-189.

Rattray, P.V.; Thompson, K.F.; Hawker, H.; Summer, R.M.W. 1987. Pastures for sheep production. pp. 89-103. In: Livestock Feeding on Pasture. New Zealand Society of Animal Production Occasional Publication No. 10.

Sangakkara, R.; Roberts, E. 1981. Competition between 'Nui' ryegrass, 'Matua' prairie grass, and 'Apanui' cocksfoot during establishment and early growth. Proceedings of the New Zealand Grassland Association 43: 133-138.

Stevens, D.R.; Baxter, G.S.; Casey, M.J.; Miller, K.B.; Lucas, R.J. 1992. A comparison of six grasses for animal production. Proceedings of the New Zealand Grassland Association 54: 147-150. 
Stevens, D.R.; Casey, M.J.; Turner, J.D.; Baxter, G.S. Miller, K.B. 1993. Grasslands Kahu timothy: quality pasture for animal performance. Proceedings of the New Zealand Grassland Association 55: 127-132.

Toddhunter, C.J. 1997. Establishment of Caucasian clover compared with white clover and red clover. B.Agr.Sc. Honours Dissertation. Lincoln University. Thom, E.R.; Thorrold, B.S.; Edgecombe, G.A. 1987. Pasture renovation: the approach. pp. 101-108. In: Pasture renovation for greater productivity. Eds. Pottinger, R.P.; Lane, P.M.S.; East, R. Ruakura Agricultural Centre, MAFTech North, Ministry of
Agriculture and Fisheries, Hamilton, New Zealand; Monsanto NZ, Cambridge, New Zealand.

Watson, R.N.; Neville, F.J.; Bell, N.L.; Harris, S.L. 1996. Caucasian clover as a pasture legume for dryland dairying in the coastal Bay of Plenty. Proceedings of the New Zealand Grassland Association 58: 183-188.

Widdup, K.H.; Knight, T.L.; Waters, C.J. 1998. Genetic variation for rate of establishment in caucasian clover. Proceedings of the New Zealand Grassland Association 60: 213-217. 
